\title{
GIANT LEFT ATRIUM THROMBOSIS ASSOCIATED WITH AN ASYMPTOMATIC MITRAL VALVE DISEASE
}

\author{
Reznik E.V.1,2, Komissarova M.S.1,2, Ustyuzhanin D.V.3, Nikitin I.G. 1,4
}

M

itral valve disease (MVD) can lead to an atrial fibrillation, a left atrium (LA) dilatation and thrombus formation. The aim of the study was to demonstrate a rare clinical case of a patient with asymptomatic MVD with the formation of the huge thrombus in the giant LA.

Material and methods. An asymptomatic 49-year-old man underwent a preventive examination for cardiovascular diseases screening. His past medical history included the chronic tonsillitis only. There were no complaints or any heart disease symptoms. The patient underwent ECG, echocardiography, and after a cardiac surgeon consultation - cardiac MRI.

Results. The ECG showed the atrial fibrillation. Echocardiography revealed a mitral valve lesion with a predominance of stenosis, a dilatation of the LA cavity with a formed mass. Cardiac MRI was performed by recommendation of the cardiac surgeon due to surgical strategy clarification and differential diagnostics with LA myxoma. MRI revealed 3 fixed blood clots in the left atrium. These findings were verified during surgery.

Conclusion. Preventive screening of cardiac diseases with ECG and echocardiography are very important in people with the history of chronic tonsillitis.

Keywords: echocardiography, MRI, mitral stenosis, mitral insufficiency, giant left atrium, huge thrombus, atrial fibrillation.

Corresponding author: Ustyuzhanin D.V., e-mail: d-ust@yandex.ru.

For citation: Reznik E.V., Komissarova M.S., Ustyuzhanin D.V., Nikitin I.G. Giant left atrium thrombosis associated with an asymptomatic mitral valve disease. REJR 2020; 1O(1):238-244. DOI:10.21569/2222-7415-2020-10-1-238-244.

Received: $\quad 30.10 .19 \quad$ Accepted: $\quad 10.02 .20$

\section{ТРОМБОЗ ГИГАНТСКОГО АЕВОГО ПРЕАСЕРАИЯ У БОАЬНОГО С БЕССИМПТОМНЫМ МИТРААЬНЫМ ПОРОКОМ СЕРАЦА}

\author{
Резник Е.В.1,2, Комиссарова М.С. 1,2, Устюжанин А.В. ${ }^{3}$, Никитин И.Г. 1,4
}

1 - N.I. Pirogov Interna Medicine Department, Russian National Research Medical University. 2 - V.M. Buyanov City Clinical Hospital. 3 - National Medical Research Center of Cardiology.

4 - Treatment and Rehabilitation Center. Moscow, Russia 
сердца с преобладанием стеноза. Также было выявлено расширение полости мевого предсердия с наличием в нем дополнительного образования. Пациент бым консультирован кардиохирургом, в плане предоперационной подготовки дмя уточнения тактики операции и дифференциальной диагностики с миксомой $\Lambda$ было рекомендовано выполнение МРТ сердца. МРТ позволило выявить 3 фиксированных тромба в $\Lambda П$. Данные находки были верифицированы при хирургической операции.

Заключение. КАинический случай показывает важность скрининга сердечнососудистых заболеваний с помощью ЭКГ и эхокардиографии у пациентов, страдающих хроническим тонзициитом.

Ключевые слова: эхокардиография, МРТ, митральный стеноз, митральная недостаточность, гигантское мевое предсердие, массивный тромб, фибримляция предсердий.

Контактный автор: Устюжанин Д.В., e-mail: d-ust@yandex.ru

Для иитирования: Резник Е.В., Комиссарова М.С., Устюжанин Д.В., Никитин И.Г. Тромбоз гигантского левого предсердия у больного с бессимптомньм митральньм пороком сердиа. REJR 2020; 10(1):238-244. DOI:10.21569/2222-7415-2020-10-1-238-244.
Статья получена:
30.10 .19
Статья принята:
10.02 .20

\section{I}

ntroduction.

The mitral valve disease is a life-threatening condition that has severe complications and a high mortality rate. The usual complications associated with mitral valve disease are atrial fibrillation and thrombus formation in the cavity of the left atrium. Often left atrium enlargement can be revealed in such patients, and sometimes with a giant left atrium formation.

A left atrium enlargement more than $8 \mathrm{~cm}$ in diameter is considered as the giant left atrium [1, 2]. Asymptomatic mitral valve disease with the formation of the huge thrombus in the giant left atrium is extremely rare.

\section{Case Presentation.}

A 49-year-old man underwent a preventive screening examination in our clinic. The patient had no medical complaints or clinical symptoms. Risk factors for cardiovascular diseases, including hypertension, diabetes and smoking were not identified. His past medical history included chronic tonsillitis only without medical supervision and treatment. He hadn't any episodes of acute rheumatic fever. The patient performed a regular physical activity and fitness.

On physical exam, his height and weight were $176 \mathrm{~cm}$ and $85 \mathrm{~kg}$, body mass index and body surface area were $27.4 \mathrm{~kg} / \mathrm{m} 2$ and $2.05 \mathrm{~m} 2$. The cardiac examination revealed irregular heart rate and heart murmur.

The electrocardiogram showed atrial fibrillation with a heart rate of $78 \mathrm{bpm}$, the vertical direction of the electrical axis of the heart, incomplete right bundle branch block. The transthoracic echocardiography revealed a dilatation of the cavity of the left atrium $(11.1 \times 9.5 \mathrm{~cm}$, left atrium area $83 \mathrm{~cm} 2)$ and a formed mass with the dimensions of $8.6 \times 5.1 \mathrm{~cm}$ within the atrial cavity (Fig. 1, 2). A mitral valve lesion with a predominance of stenosis was detected by Doppler ultrasound with maximal velocity of $2.32 \mathrm{~m} / \mathrm{s}$ and a mitral valve pressure gradient of $21.5 / 9.2 \mathrm{~mm} \mathrm{Hg}$ (Fig. 3). Mitral valve area was $0.65 \mathrm{~cm} 2$. Moderate mitral and tricuspid regurgitations were also revealed. The pulmonary artery systolic pressure was $26 \mathrm{~mm}$ $\mathrm{Hg}$. The left ventricle ejection fraction (Simpson method) was normal (65.6\%). Mitral valve disease with a predominance of stenosis was diagnosed.

Oral anticoagulant therapy Warfarin $5 \mathrm{mg}$ daily, beta-blocker Bisoprolol $2.5 \mathrm{mg}$ daily, and urgent consultation with a cardiac surgeon were prescribed. Cardiac surgery with extraction and histological verification of the left atrium mass and atrial reconstruction after detailed preoperative examination was planned.

The cardiac magnetic resonance imaging (MRI) was performed to exclude left atrium myxoma and for more accurate surgical planning. MRI is an accurate diagnostic method to assess the anatomy of the left atrium [3] and determine the presence of a blood clot.

Non-contrast 1.5 T MRI confirmed a severe left atrial enlargement (dimensions 9x12x11 cm), and revealed 3 thrombotic masses: the first was $5.3 \times 3.4 \mathrm{~cm}$ on the lower wall, the second was $3.8 \times 3.0 \mathrm{~cm}$ on the upper wall, and the third was $1.6 \times 1.6 \times 3.0 \mathrm{~cm}$ on the left side wall, with a heterogeneous structure, affixed by a wide base to the atrial wall, without significant flotation (Figure 4). MRI area of the mitral valve opening was $1.9 \mathrm{~cm} 2$.

Data from laboratory analyses and imaging examinations did not indicate a cancer, thrombophilia, connective tissue diseases, thyroid disorders, or any clinically significant deviations. 


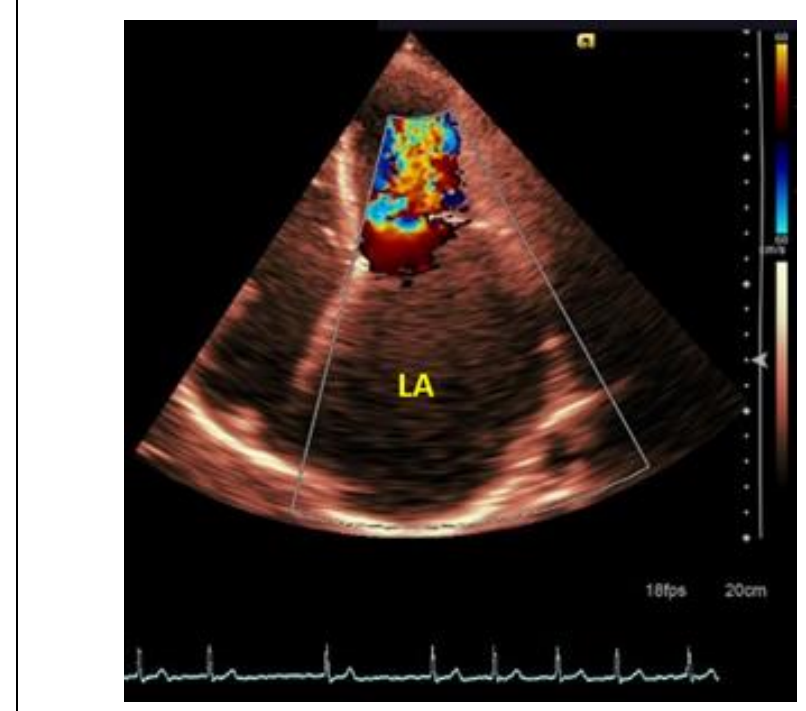

Fig. 1 a (Pис. 1 a)



Fig. 1 b (Рис. 1 б)

Fig. 1. The transthoracic echocardiography.

$\mathrm{a}$ - the apical four-chamber view with color Doppler. $\mathrm{b}$ - the apical two-chamber view. The giant left atrium (LA) can be seen.

Рис. 1. Трансторакальная эхокарАиография, апикальный Аоступ.

a - четырехкамерная проекция с цветным допплеровским картированием. б - двухкамерная проекция. Выраженное расширение полости мевого предсердия (обозначено как LA).



Fig. 2 a (Рис. 2 a)

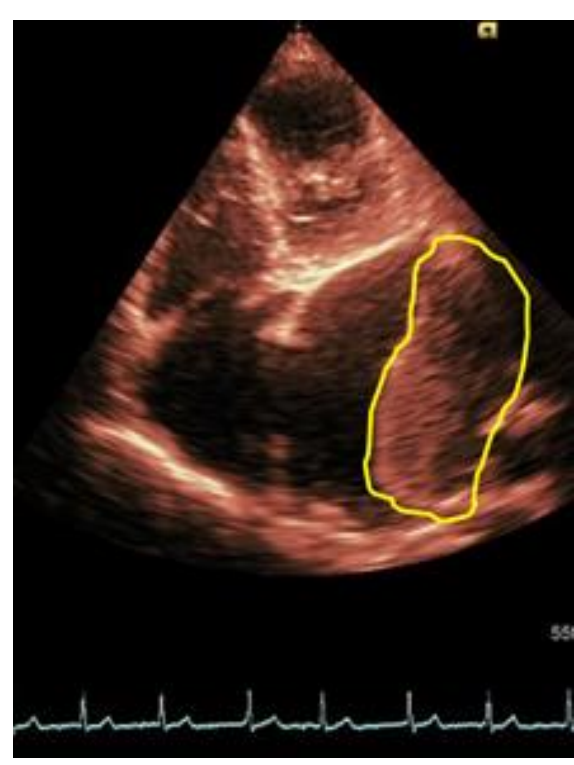

Fig. 2 b (Рис. 2 б)

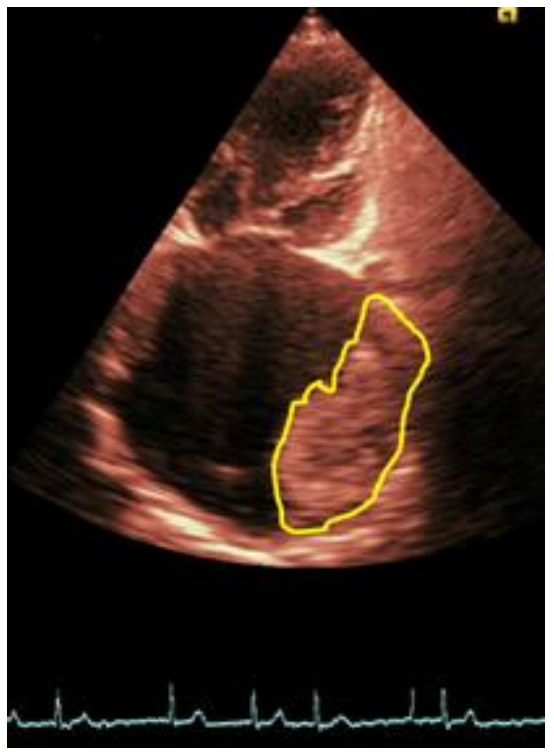

Fig. 2 b (Рис. 2 б)

Fig. 2. The transthoracic echocardiography, the positive mass in the left atrium (the yellow contours). $\mathrm{a}$ - the parasternal long axis view. $\mathrm{b}$ - the apical four-chamber view. $\mathrm{c}$ - the apical two-chamber view.

Рис. 2. Трансторакальная эхокарАиография, гиперэхогенное образование в левом преАсерАии (обозначено желтым контуром).

a - проекция по длинной оси, парастернальный доступ. б - апикальная четырехкамерная проекция. в двухкамерная проекция. 


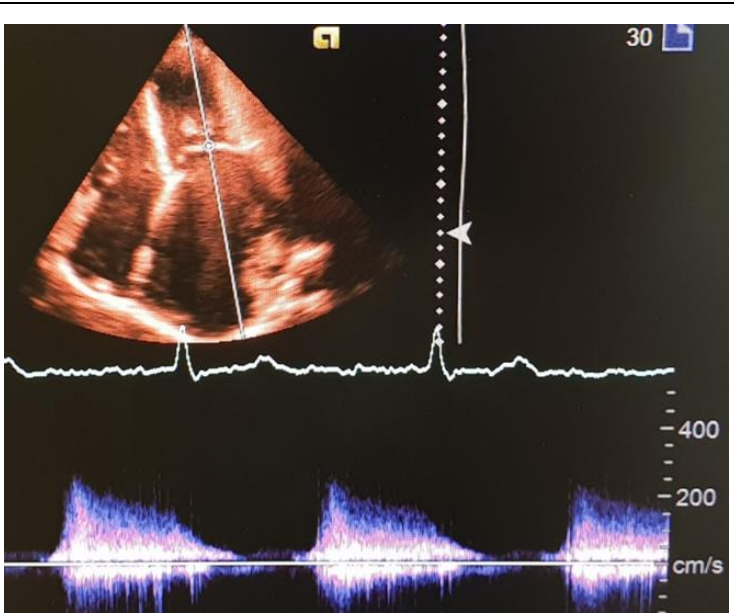

Fig. 3 (Рис. 3)

Fig. 3. The transthoracic echocardiography, continuous Doppler of the transmitral flow from the apical four-chamber view.

The mitral valve disease with increased blood flow velocity (V $\max 2.32 \mathrm{~m} / \mathrm{s}$ ) and pressure gradients (maximum $21.5 \mathrm{~mm} \mathrm{Hg}$, mean $9.2 \mathrm{~mm} \mathrm{Hg}$ ).

Рис. 3. Трансторакальная эхокарАиография, непрерывное спектральное Аопплеровское картирование трансмитрального потока из апикального четырехкамерного сечения.

Выявлен комбинированный митральный порок сердца с повышением скорости кровотока (V max $2,32 \mathrm{M} / \mathrm{c}$ ) и градиентов давления (максимальный 21,5 мм. рт. ст., средний 9,2 мм. рт. ст).
Selective coronary angiography determined dextral blood supply to the myocardium and intact coronary arteries. A 24-h Holter monitoring electrocardiogram identified ventricular extrasystoles according to Lown and Wolff IV B grading, and one episode of asymptomatic non-sustained ventricular tachycardia (4 complexes).

Mitral valve replacement by mechanical prosthesis On-X 31 was performed with preservation of the posterior subvalvular structures, removal of the blood clots from the left atrium (Fig. 5), and a tricuspid annuloplasty on the band. Histological examination confirmed the thrombotic nature of the masses in the left atrium.

There were non-sustained ventricular tachycardia and atrial flutter in the early postoperative period.

Treatment by Bisoprolol $5 \mathrm{mg}$, Amiodarone $200 \mathrm{mg}$, Warfarin $5 \mathrm{mg}$ with international normalized ratio control, Acetylsalicylic acid $100 \mathrm{mg}$, Pantoprazole $40 \mathrm{mg}$ daily were prescribed.

On a scheduled examination in a month after surgery transthoracic echocardiography revealed no clot or masses in the left atrium, the function of the mitral valve prosthesis was satisfactory (Fig. 6). The pressure gradient on the prosthesis was $11.4 / 3.8 \mathrm{~mm} \mathrm{Hg}$.

Discussion.

The giant left atrium is a rare condition (incidence of $0.3 \%$ in the rheumatic heart disease). It is mainly associated with the mitral stenosis and the atrial fibrillation [4].



Fig. 4 a (Рис. 4 a)

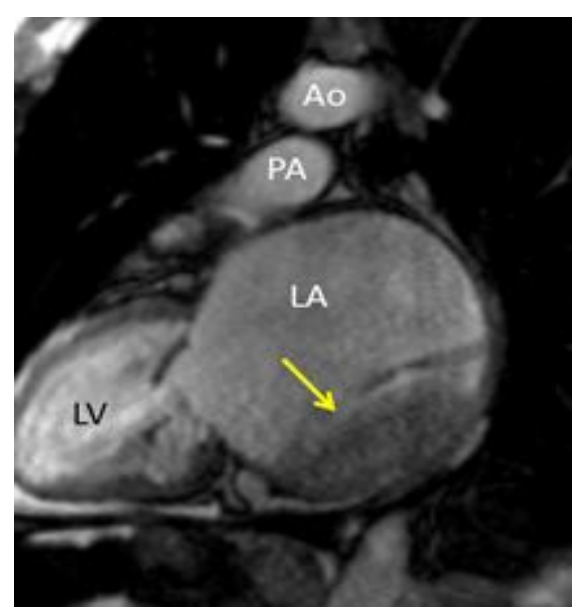

Fig. 4 b (Рис. 4 б)

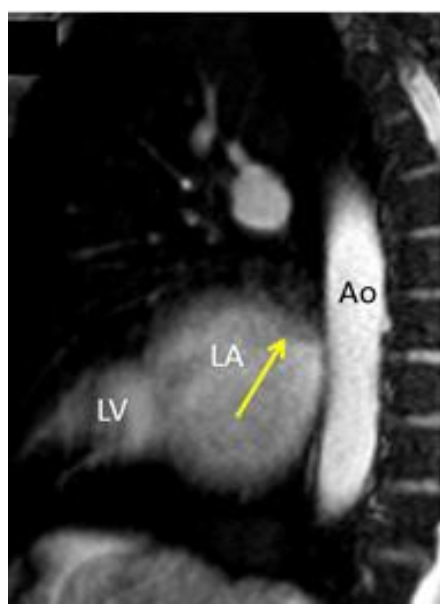

Fig. 4 с (Рис. 4 в)

Fig. 4. Cardiac MRI, non-contrast images in diastole.

a, c - oblique slices, b - long axis two-chamber view. Three thrombotic masses were found in the left atrium (arrows). LA - left atrium, LV - left ventricle, Ao - aorta, PA - pulmonary artery.

Рис. 4. МРТ серАца, изображения без ввеАения контрастного препарата, Аиастола.

а, в - косые срезы, б - двухкамерная проекция по диинной оси мевого желудочка. В мевом предсердии выяв-


гочная артерия. 


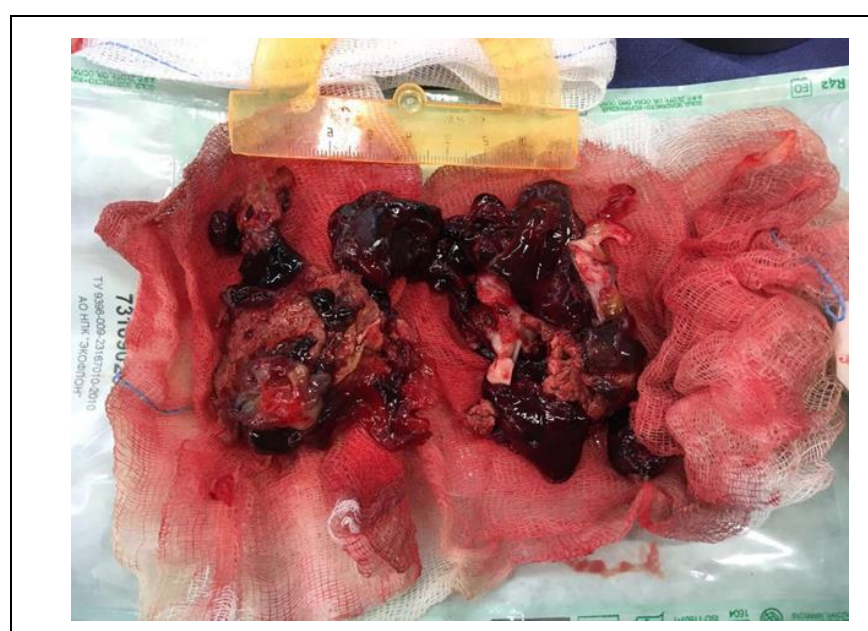

Fig. 5 (Pис. 5)

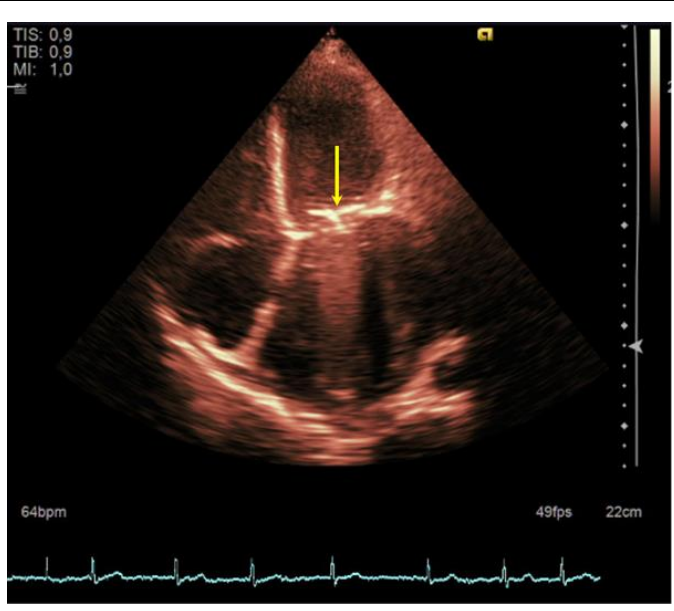

Fig. 6 (Рис. 6)

\section{Fig. 5. Gross specimen after the operation.}

The blood clot extracted from the left atrium.

Рис. 5. Макропрепарат после операции.

Тромботические массы, извлеченные из мевого предсердия.

A search for "Giant left atrium with/without blood clots" was performed on the PubMed and Web of Science databases. 55 suitable clinical cases were selected and analyzed. The giant left atrium without cavity blood clots was described in 26 of the 55 articles. All patients in those cases had a history of rheumatic heart disease with mitral valve replacement and pronounced clinical symptoms requiring emergency hospitalization. The maximum described left atrium size was $20.9 \times 9.6 \mathrm{~cm}$ revealed by transthoracic echocardi

ography in a 58-year-old patient [5]. 12 of the articles described clinical cases of giant left atrium, with thrombi in the left atrium cavity [6-17]. The largest left atrium blood clot was $11.5 \times 6.6 \mathrm{~cm}$, detected by transthoracic echocardiography in a 50-year-old patient with a mitral valve replacement, complaining of left-sided hemiparesis [6]. All patients in the cases had a history of chronic rheumatic heart disease with mitral valve replacement, atrial fibrillation and severe clinical symptoms requiring hospital treatment. The most interesting features in our clinical case are the absence of any patient complaints and no history of cardiovascular diseases, while one of the largest blood clot masses described in the scientific literature was found [7-9].

Rheumatic heart disease (RHD) is a preventable chronic cardiovascular condition, which affects more than 30 million individuals worldwide
Fig. 6. The transthoracic echocardiography, the mitral prosthesis (the arrow), the apical fourchamber view.

No blood clot or masses in the left atrium

Рис. 6. Трансторакальная эхокардиография, апикальная четырехкамерная проекция.

Объемных образований и тромботических масс в $е$ вом предсердии не выявлено. Виден установленный протез митрального клапана (обозначен стрелкой).

and is responsible for about 300000 deaths annually. These deaths mostly occur among children and young adults living in low- and middleincome countries and among indigenous populations of some high-income countries [18-19]. With the recent increasing migrant flows toward developed countries, it is going to become a less infrequent finding of marked discrepancy between mitral disease severity and patients' symptoms (most cases in young people).

The clinical case demonstrates that serious complications of the mitral valve disease such as atrial fibrillation, the giant left atrium cavity and thrombus formation may be completely asymptomatic. Regular preventive screening examinations with electrocardiogram and echocardiography in patients with a history of chronic tonsillitis can be useful for early detection of such conditions, and for the prevention of complications.

\section{Conclusion.}

The giant left atrium, atrial fibrillation and the thrombus formation in patient with asymptomatic mitral valve disease is extremely rare in clinical practice. The presented clinical case shows the importance of preventive screening of cardiac diseases with ECG and echocardiography in people with the history of chronic tonsillitis. 


\section{RUSSIAN ELECTRONIC JOURNAL OF RADIOLOGY}

\section{Список митературы:}

1. Loch A., Sadiq M. A., Wan Ahmad W. A. Giant Left Atrium in a Patient with Prosthetic Mitral Valve. European Heart Journal 2013; 34(13):981. DOI: 10.1093/eurheartj/eht021.

2. Piccoli G. P., Massini C., Di Eusanio G., Ballerini L., Iacobone G., Soro A., Palminiello A. Giant Left Atrium and Mitral Valve Disease: Early and Late Results of Surgical Treatment in 40 Cases. The Journal of Cardiovascular Surgery 1984; 25(4):328336.

3. Белькинд М.Б., Шария М.А., Добровольская С.В., Терновой C.K. Аневризма левого предсердия. REJR 2017; 7(3):183-187. DOI:10.21569/2222-7415-2017-7-3-183-187.

4. Muthiah R. Rheumatic Giant Left Atrium-An Overview. Case Reports in Clinical Medicine 2017; 06(06):164-195. DOI: 10.4236/crcm.2017.66017.

5. Kucukdurmaz Z., Gunes H., Kurt R., Karapinar H. Giant Left Atrium. Echocardiography 2013; 30(4):E110. DOI: 10.1111/echo. 12082 .

6. Akdemir I., Davutoglu V., Aksoy M. Giant Left Atrium, Giant Thrombus, and Left Atrial Prolapse in a Patient with Mitral Valve Replacement. Echocardiography 2002; 19(8):691-692.

7. Darwazah A. K., El Sayed H. Giant Left Atrium Associated with Massive Thrombus Formation. Thrombosis Journal 2013; 11(1):5. DOI: 10.1186/1477-9560-11-5.

8. Dedeilias P., Roussakis A., Koletsis E. N., Zervakis D., Hountis P., Prokakis C., Balaka C., Bolos K. Left Atrial Giant Thrombus Infected by Escherichia Coli. Case Report. Journal of Cardiothoracic Surgery 2008; 3: 318. DOI: 10.1186/1749-80903-18.

9. Gackowski A., Piwowarska W., Pfitzner R., Nessler J., Konduracka E. Gigantic Left Atrial Thrombus. European Heart Journal 2007; 28(8):1032. DOI: 10.1093/eurheartj/ehl326.

10. Giuliano Serafino C., Baptista M. L., Rosa V. E. E., Lopes A. S. de S. A., Accorsi T. A. D., Tarasoutchi F. Giant Left Atrial Thrombus with Double Coronary Vascularization. Arquivos Brasileiros de Cardiologia 2015; 104(2):e15-e17. DOI: 10.5935/abc. 20140128.

11. Hodzic E., Granov N. Gigantic Thrombus of the Left Atrium in Mitral Stenosis. Medical Archives 2017; 71(6):449-452. DOI:

\section{References:}

1. Loch A., Sadiq M. A., Wan Ahmad W. A. Giant Left Atrium in a Patient with Prosthetic Mitral Valve. European Heart Journal 2013; 34(13):981. DOI: 10.1093/eurheartj/eht021.

2. Piccoli G. P., Massini C., Di Eusanio G., Ballerini L., Iacobone G., Soro A., Palminiello A. Giant Left Atrium and Mitral Valve Disease: Early and Late Results of Surgical Treatment in 40 Cases. The Journal of Cardiovascular Surgery 1984; 25(4):328336.

3. Belkind M.B., Shariya M.A., Dobrovolskaya S.V., Ternovoy S.K. Left atrial aneurysm. REJR 2017; 7(3):183-187. DOI:10.21569/2222-7415-2017-7-3-183-187 (in Russian).

4. Muthiah R. Rheumatic Giant Left Atrium-An Overview. Case Reports in Clinical Medicine 2017; 06(06):164-195. DOI: 10.4236/ crcm.2017.66017.

5. Kucukdurmaz Z., Gunes H., Kurt R., Karapinar H. Giant Left Atrium. Echocardiography 2013; 30(4):E110. DOI: 10.1111/echo.12082.

6. Akdemir I., Davutoglu V., Aksoy M. Giant Left Atrium, Giant 10.5455/medarh.2017.71.449-452.

12. Intorcia A., Perrone M. A., Morgagni R., Sergi D., Marchei M., Borzi M., Romeo F. A Rare Case of Multiple Thrombi in a Giant Left Atrium. Journal of Cardiovascular Medicine 2017; 18(10):837-838. DOI: 10.2459/JCM.0000000000000535.

13. Lee J. H., Kang S. K., Lee C. W., Song J. K., Park J. S., Choo S. J. Giant Left Atrial Ball Thrombus in a Patient with Chronic Nonvalvular Atrial Fibrillation. The Annals of Thoracic Surgery 2008; 85(1):313-315. DOI: 10.1016/j.athoracsur.2007.07.084.

14. Okyay K., Cengel A., Tavil Y. Images in Cardiology. A Giant Left Atrium with Two Huge Thrombi without Embolic Complications. The Canadian Journal of Cardiology 2007; 23(13):1088.

15. Rost C., Daniel W. G., Schmid M. Giant Left Atrial Thrombus in Moderate Mitral Stenosis. European Journal of Echocardiography: The Journal of the Working Group on Echocardiography of the European Society of Cardiology 2009; 10(2):358-359. DOI: 10.1093/ejechocard/jen255.

16. Shao Q., Tian R., Zhang X., Gao X., Lai J., Tian Z., Yan X., Zhang S. Chronic Disseminated Intravascular Coagulation Induced by Left Atrial Thrombus in a Patient with Giant "Normal" Heart: A Case Report. Medicine 2016; 95(51):e5501. DOI: 10.1097/MD.0000000000005501.

17. Ying Z.-Q., Ma J., Xu G. Giant Left Atrium. European Heart Journal 2008; 29(3):295. DOI: 10.1093/eurheartj/ehm383.

18. Nishimura R. A., Otto C. M., Bonow R. O., Carabello B. A., Erwin J. P., Fleisher L. A., Jneid H., Mack M. J., McLeod C. J., O'Gara P. T., Rigolin V. H., Sundt T. M., Thompson A. 2017 AHA/ACC Focused Update of the 2014 AHA/ACC Guideline for the Management of Patients With Valvular Heart Disease: A Report of the American College of Cardiology/American Heart Association Task Force on Clinical Practice Guidelines. Journal of the American College of Cardiology 2017; 70(2):252-289. DOI: 10.1016/j.jacc.2017.03.011.

19. Wauchop K., Shetty A., Bremner C. The Epidemiology of Acute Rheumatic Fever in Northland, 2012-2017. The New Zealand Medical Journal 2019; 132(1498):32-40.

Thrombus, and Left Atrial Prolapse in a Patient with Mitral Valve Replacement. Echocardiography 2002; 19(8):691-692.

7. Darwazah A. K., El Sayed H. Giant Left Atrium Associated with Massive Thrombus Formation. Thrombosis Journal 2013; 11(1):5. DOI: 10.1186/1477-9560-11-5.

8. Dedeilias P., Roussakis A., Koletsis E. N., Zervakis D., Hountis P., Prokakis C., Balaka C., Bolos K. Left Atrial Giant Thrombus Infected by Escherichia Coli. Case Report. Journal of Cardiothoracic Surgery 2008; 3: 318. DOI: 10.1186/1749-80903-18.

9. Gackowski A., Piwowarska W., Pfitzner R., Nessler J., Konduracka E. Gigantic Left Atrial Thrombus. European Heart Journal 2007; 28(8):1032. DOI: 10.1093/eurheartj/ehl326.

10. Giuliano Serafino C., Baptista M. L., Rosa V. E. E., Lopes A. S. de S. A., Accorsi T. A. D., Tarasoutchi F. Giant Left Atrial Thrombus with Double Coronary Vascularization. Arquivos Brasileiros de Cardiologia 2015; 104(2):e15-e17. DOI: 10.5935/abc.20140128. 


\section{RUSSIAN ELECTRONIC JOURNAL OF RADIOLOGY}

11. Hodzic E., Granov N. Gigantic Thrombus of the Left Atrium in Mitral Stenosis. Medical Archives 2017; 71(6):449-452. DOI: 10.5455/medarh.2017.71.449-452.

12. Intorcia A., Perrone M. A., Morgagni R., Sergi D., Marchei M., Borzi M., Romeo F. A Rare Case of Multiple Thrombi in a Giant Left Atrium. Journal of Cardiovascular Medicine 2017; 18(10):837-838. DOI: 10.2459/JCM.0000000000000535.

13. Lee J. H., Kang S. K., Lee C. W., Song J. K., Park J. S., Choo S. J. Giant Left Atrial Ball Thrombus in a Patient with Chronic Nonvalvular Atrial Fibrillation. The Annals of Thoracic Surgery 2008; 85(1):313-315. DOI: 10.1016/j.athoracsur.2007.07.084.

14. Okyay K., Cengel A., Tavil Y. Images in Cardiology. A Giant Left Atrium with Two Huge Thrombi without Embolic Complications. The Canadian Journal of Cardiology 2007; 23(13):1088.

15. Rost C., Daniel W. G., Schmid M. Giant Left Atrial Thrombus in Moderate Mitral Stenosis. European Journal of Echocardiography: The Journal of the Working Group on Echocardiography of the European Society of Cardiology 2009; 10(2):358-359. DOI: $10.1093 /$ ejechocard/jen255.
16. Shao Q., Tian R., Zhang X., Gao X., Lai J., Tian Z., Yan X., Zhang S. Chronic Disseminated Intravascular Coagulation Induced by Left Atrial Thrombus in a Patient with Giant "Normal" Heart: A Case Report. Medicine 2016; 95(51):e5501. DOI: 10.1097/MD.0000000000005501.

17. Ying Z.-Q., Ma J., Xu G. Giant Left Atrium. European Heart Journal 2008; 29(3):295. DOI: 10.1093/eurheartj/ehm383.

18. Nishimura R. A., Otto C. M., Bonow R. O., Carabello B. A., Erwin J. P., Fleisher L. A., Jneid H., Mack M. J., McLeod C. J., O'Gara P. T., Rigolin V. H., Sundt T. M., Thompson A. 2017 AHA/ACC Focused Update of the 2014 AHA/ACC Guideline for the Management of Patients With Valvular Heart Disease: A Report of the American College of Cardiology/American Heart Association Task Force on Clinical Practice Guidelines. Journal of the American College of Cardiology 2017; 70(2):252-289. DOI: 10.1016/j.jacc.2017.03.011.

19. Wauchop K., Shetty A., Bremner C. The Epidemiology of Acute Rheumatic Fever in Northland, 2012-2017. The New Zealand Medical Journal 2019; 132(1498):32-40. 